\title{
Performance of an acid stable nanofiltration membrane for nickel removal from aqueous solutions: effects of concentration, solution pH and ionic strength
}

\author{
O. Agboola ${ }^{1}$, J. J. Schoeman ${ }^{2}$, J. Maree ${ }^{1}$, \\ R. Mbaya ${ }^{1} \&$ A. Kolesnikov ${ }^{1}$ \\ ${ }^{I}$ Department of Chemical and Metallurgical Engineering, \\ Tshwane University of Technology, Pretoria, South Africa \\ ${ }^{2}$ Department of Chemical Engineering, Water Utilisation Division, \\ University of Pretoria, South Africa
}

\begin{abstract}
The performance of a nanofiltration membrane for the removal of the nickel ion was studied as a function of the nickel concentration, solution $\mathrm{pH}$, and the background ionic strength of the solution. Nanofiltration is investigated as a means to determine to what extent the nickel ions could be removed from acid mine drainage; thus the effect of solution chemistry on nanofiltration performance is investigated. Higher fluxes $\left(47.61 / \mathrm{m}^{2} / \mathrm{h}\right)$ were experienced at the lower nickel concentration $(10 \mathrm{mg} / \mathrm{l})$ than at the higher $\left(28.91 / \mathrm{m}^{2} / \mathrm{h}\right)$ nickel concentration $(100 \mathrm{mg} / \mathrm{l})$. Higher nickel ion rejections $(97.3 \%)$ were obtained at the higher nickel concentration $(100 \mathrm{mg} / \mathrm{l})$ than at the lower nickel concentration (93.6\%). Higher flux was obtained at the higher $\mathrm{pH}(\mathrm{pH} 4)$ with a $0.01 \mathrm{M} \mathrm{NaCl}$ background solution than at lower $\mathrm{pH}(\mathrm{pH} 3)$ when a $0.05 \mathrm{M} \mathrm{NaCl}$ was used as background solution. Higher nickel ion rejections were obtained at higher $\mathrm{pH}$ $(\mathrm{pH} 4)$ for the two ionic strength background solutions. Higher fluxes were also obtained with the lower $\mathrm{NaCl}$ background solution. Slightly higher ion rejections were obtained with the lower $\mathrm{NaCl}$ background concentration. It therefore appears that this nanofiltration membrane should be successfully applied for the removal of nickel ions from acid mine drainage.

Keywords: nanofiltration, acid mine drainage, nickel removal, nickel rejection, fluxes, nickel concentrations, solution $\mathrm{pH}$, ionic strength.
\end{abstract}




\section{Introduction}

The pollution of surface waters by metal ions originating from acidic effluents $(\mathrm{As}, \mathrm{Pb}, \mathrm{Fe}, \mathrm{Ni}, \mathrm{Cd}, \mathrm{Mg}, \mathrm{Mn}$ ) from refineries, electroplating effluents $(\mathrm{Cu}, \mathrm{Ni}$, $\mathrm{Pb}, \mathrm{Zn}, \mathrm{Cr}$ ) and from acid mine drainage (Fe, $\mathrm{Al}, \mathrm{Cu}, \mathrm{Mg}, \mathrm{Ni}, \mathrm{Zn}$ ) can cause serious problems because of their toxicity [1-3]. These problems have stimulated research the last number of years to study appropriate methods for their removal from water. Nanofiltration is one method that should be effectively applied for the removal of heavy metal ions from effluents [4].

Several studies have been conducted the last number of years to identify the different factors involved in the rejection of metal cations by nanofiltration membranes. Akbari et al. [5] investigated the effect of solution chemistry and operating conditions on the nanofiltration of acid dyes by a nano-composite membrane. Their study showed that the rejections of sodium chloride and sodium sulphate were moderate and declined with increasing feed concentration. It was also found that by changing the $\mathrm{pH}$, the membrane surface and the dyes charge changed. Their result showed that the membrane surface and dyes had different interactions at different $\mathrm{pH}$ values.

Dipankar et al. [6] studied the effect of solution chemistry on water softening using charged nanofiltration membranes. They found that the flux declined with increasing ionic concentration of the feed solution. Shäfer et al. [7] investigated effects of solution chemistry on the retention of low molecular mass acids versus bulk organic matter by nanofiltration. Their results emphasized that the charge and size of the cations and acids are important for separation.

Dahmani and Chabene [8] studied the effect of solution chemistry on the performance of a nanofiltration membrane for nickel removal from an aqueous solution. They found that the solution $\mathrm{pH}$, feed concentration and the ionic strength of the solution affected ion rejection and flux. Choo et al. [9] studied the selective removal of cobalt species from simulated nuclear liquid waste with different nanofiltration (NF) membranes at different solution $\mathrm{pH}$ levels, different cobalt concentrations, and different ion background concentrations. Their study provided insight into the understanding of the relationships between rejections of a target compound (cobalt) and the chemical equilibria of different species in the feed solution during nanofiltration.

Acid mine drainage containing high concentrations of iron, manganese, cobalt, nickel, etc., is of major concern when it leaks into the water environment. An acid stable nanofiltration membrane which has the potential to operate at low $\mathrm{pH}(\mathrm{pH} 2)$ has the potential to treat acid mine drainage effectively. Therefore, the objective of this investigation is to evaluate the use of the acid stable membrane for the removal of the nickel ion and other cations occurring in acid mine drainage with this and other membranes. 


\section{Experimental}

\subsection{Nanofiltration membrane characteristics}

A composite nanofiltration membrane (Nano-Pro A 3012) was chosen for this research as representative of a class of membranes which are acid stable in water treatment applications. According to the manufacturer, the maximum operating pressure is 40 bar $(580 \mathrm{psi})$, maximum operating temperature $50^{\circ} \mathrm{C}\left(122^{\circ} \mathrm{F}\right)$, allowable $\mathrm{pH}$ - Continuous Operation: 0-12, Recirculation Flow Rate: Minimum 90L/min (24gpm), Maximum 280L/min (74 gpm).

\subsection{Analytical method}

Nickel ion concentration was analysed by using inductively coupled plasma optical emission. Measurements of solution $\mathrm{pH}$ and temperature were made using a $\mathrm{pH}$ meter (Mettler Toledo FG20) purchased from Microsep and thermometer, respectively. The ionic strengths were calculated using a correlation between conductivity and ionic strength of a $\mathrm{NaCl}$ standard, I.S. [M] $=1 / 2 \sum C_{i} Z_{i}^{2}\left(C_{i}\right.$ is the ion concentration and $Z_{i}$ is the number of ions).

\subsection{Flux decline experiments}

The experiments were carried out with one liter of solution containing a nickel sulphate solution $\left(\mathrm{NiSO}_{4}\right)$ with concentrations of 10 and $100 \mathrm{mg} / \mathrm{L}$. The solution $\mathrm{pH}$ was varied from 3 and 4 and the effect of ionic strengths $(0.01 \mathrm{M}, 0.05 \mathrm{M}$ as $\mathrm{NaCl}$ ) on flux was investigated. Flux decline experiments were conducted by using a $1000-\mathrm{ml}$ dead-end membrane filtration apparatus (Memcon South Africa) with magnetic stirrer. A membrane sheet was fitted to the cell. The membrane active area is about $0.01075 \mathrm{~m}^{2}$. The operating pressure was employed via high-pressure regulator and a nitrogen gas cylinder. The permeate flux was collected in a beaker on the electrical balance and the permeate mass was determined.

\subsection{Filtration experiments}

Membrane sheet stored in $0.7 \% \mathrm{w} / \mathrm{w}$ benzalkonium chloride at $2-30^{\circ} \mathrm{C}$ was used for the study. The membrane sheet was initially rinsed in clean distilled water and was used to measure the clean water flux (CWF) using distilled water before each nickel solution was used with the system. The clean water flux experiments were done to see if membrane did not foul. The clean water flux was done at stirring velocity rate of $500 \mathrm{rpm}$ and a pressure of 30 bar. Feed nickel solutions were prepared for each test condition. After filtration was terminated, the membrane was cleaned with deionized water, followed by a clean water flux measurement. The water fluxes at different operating conditions were measured to determine water flux recovery. 


\subsection{Laboratory dead-end test cell}

The investigation was done using a Memcon Laboratory Stirring Cell as shown in fig. 1. The membrane tested was placed in the cell. A litre of sample was then placed in the cell at the product inlet. Pressure was then applied with nitrogen gas and the permeate collected and its mass determined.

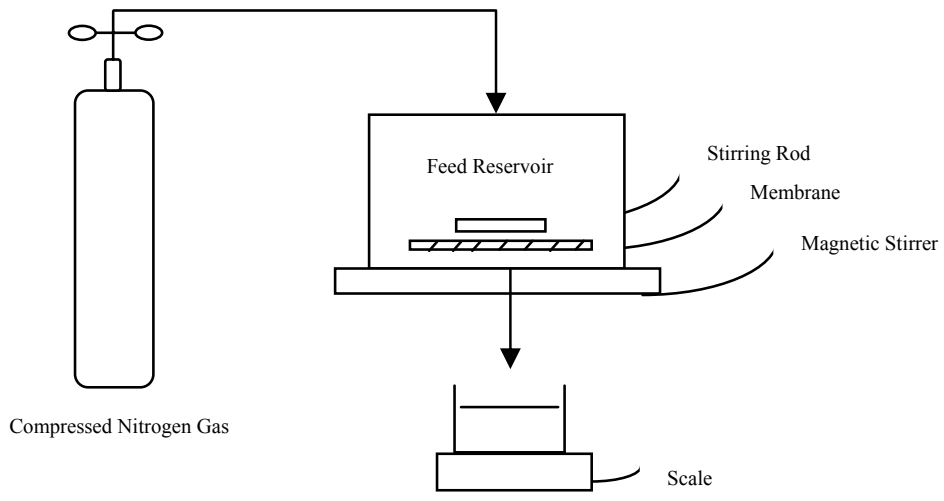

Figure 1: Schematic diagram of laboratory dead-end filtration system.

\subsection{Analysis of results}

The permeate flux and rejection were investigated as a function of working parameters such as operating time and water recovery. The permeate flux $J_{v}$ $\left(1 / \mathrm{m}^{2} / \mathrm{h}\right)$ was determined by measuring the volume of permeate collected in a given time interval divided with membrane area by the relation:

$$
J_{v}=\frac{Q}{A}
$$

where, $Q$ and $A$ represents flow rate of permeate and the membrane area, respectively.

The observed rejection which is the measure of how well a membrane retains a solute was calculated by the following relation:

$$
\% R=\left(1-\frac{C_{p}}{C_{i}}\right) \times 100
$$

where $C_{p}$ and $C_{i}$ are the solution concentrations in the permeate and in the initial feed solution, respectively. 


\section{Results and discussions}

\subsection{Clean water flux as a function of pressure}

Clean water flux as a function of pressure was done for three different pressures $(30,20$, and 10 bar) before nickel was added to the feed solutions to establish initial conditions and to determine the effect of pressure on flux. The fluxes as a function of time and water recovery are shown in fig. 2 . The feed pressure had a significant effect on nanofiltration membrane performance. A relatively high flux $\left(46.94 \mathrm{l} / \mathrm{m}^{2} / \mathrm{h}\right)$ was obtained at $30 \mathrm{bar}$ and the flux decreased significantly at 20 bar $\left(28.10 \mathrm{l} / \mathrm{m}^{2} / \mathrm{h}\right)$ and 10 bar $\left(16.29 \mathrm{l} / \mathrm{m}^{2} / \mathrm{h}\right)$. It is also intresting to note that the flux declined a little bit with increasing water recovery as a result of the higher osmotic pressure of the feed solution. However, the decline on the flux was not very much. These fluxes are low for a nanofiltration membrane and it was decided to conduct all subsequent runs at a pressure of $30 \mathrm{bar}$.

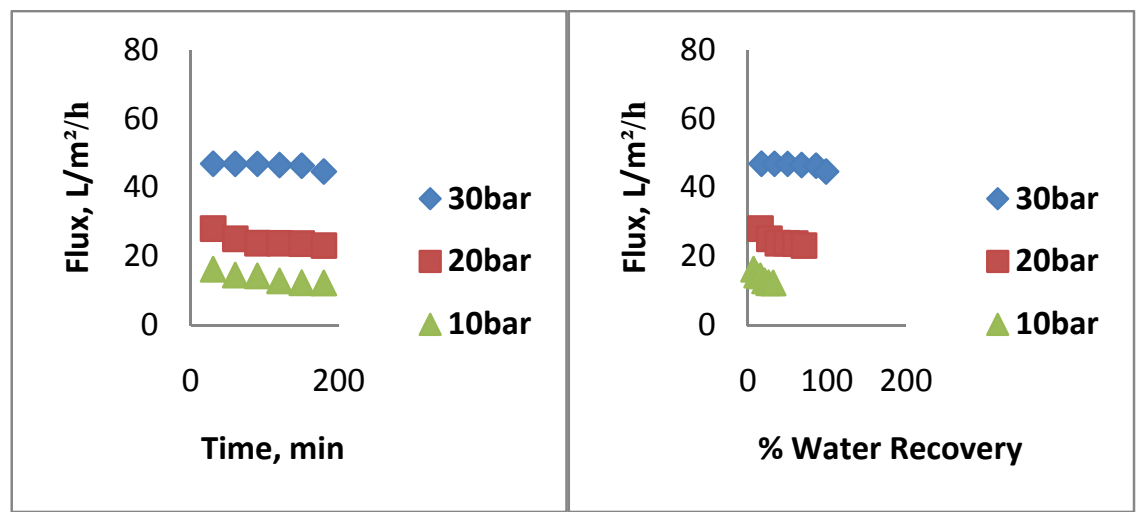

(a)

Figure 2: Flux of deionized water as function of time and water recovery (30 bar).

\subsection{Effect of solution concentration on flux and ion rejection}

The effect of nickel ion concentration on permeate flux and ion rejection is shown in figs. 3 and 4, respectively. Permeate flux was higher at the lower concentration and lower at the higher concentration (fig. 3). The lower flux at the higher concentration could be ascribed to the higher osmotic pressure of the solution at the higher concentration. It also appeared that the flux remained reasonably constant over the water recovery range tested despite the higher nickel concentration at the membrane surface with increasing recovery. Permeate flux is also low (approximately $30 \mathrm{l} / \mathrm{m}^{2} / \mathrm{h}$ for the $100 \mathrm{mg} / \mathrm{l}$ nickel concentration and approximately $45 \mathrm{l} / \mathrm{m}^{2} / \mathrm{h}$ for the $10 \mathrm{mg} / \mathrm{l}$ nickel concentration). 


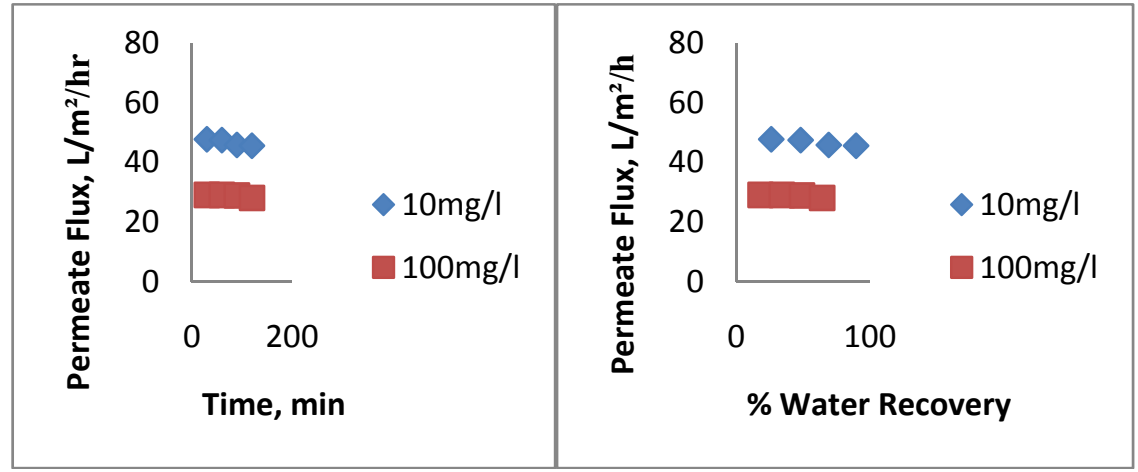

(a)

Figure 3: Effect of solution concentration on flux decline; (a) as function of time and (b) as a function of water recovery.

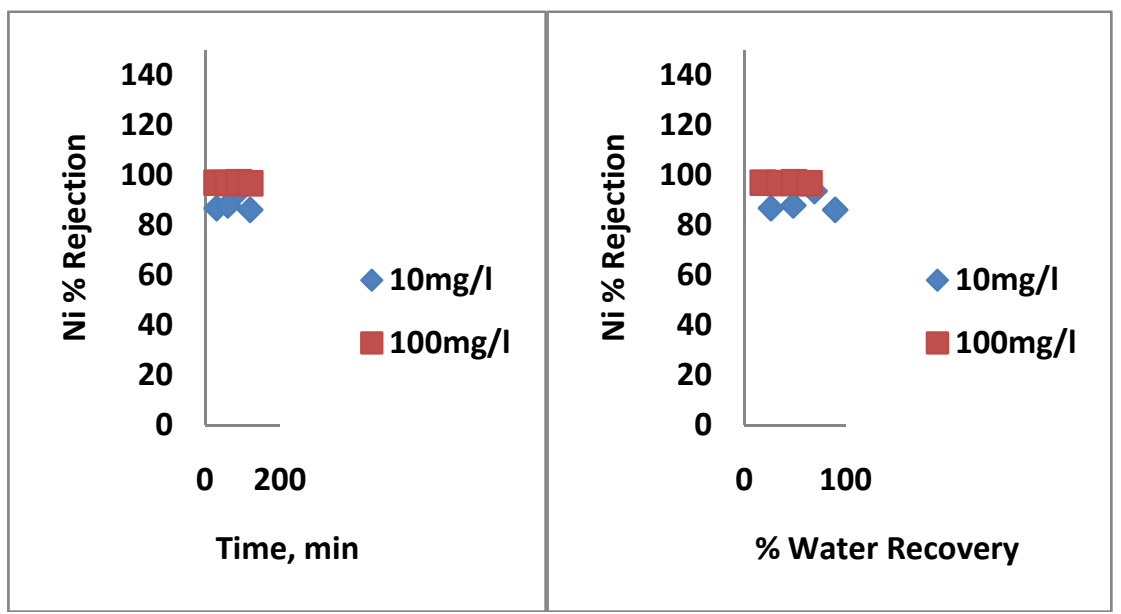

(a)

(b)

Figure 4: Effect of solution concentration on nickel ion rejection; (a) as function of time and (b) as a function of water recovery (30 bar).

The nickel ion rejection was slightly higher at the higher nickel concentration (96-97\%) than at the lower nickel concentration (86- 93.6\%) (fig. 4). The nickel ion rejection did not change much with increasing water recovery. However, the nickel ion rejection was slightly lower at higher water recovery probably due to some leakage of nickel ion through the membrane at higher water recovery. These findings for permeate flux and ion rejection as a function of concentration are in correspondence with findings of Dahmani and Chabene [8]. They, however, used a NF -90 membrane from Dow-Film Tec in their studies. 


\subsection{Effects of solution pH and ionic strength on flux}

The effect of solution $\mathrm{pH}$ on flux is shown in fig. 5. for a $\mathrm{NaCl}$ background solution of 0.01 and $0.05 \mathrm{M}(10 \mathrm{mg} / 1$ nickel). A higher permeate flux was experienced at the higher $\mathrm{pH}(\mathrm{pH} 4)\left(37.791 / \mathrm{m}^{2} / \mathrm{h}\right)$ than at lower $\mathrm{pH}(\mathrm{pH} 3)$ $\left(35.15 \mathrm{l} / \mathrm{m}^{2} / \mathrm{h}\right)$ for both the 0.01 and $0.05 \mathrm{M}$ background solutions. A higher permeate flux $\left(35.15 \mathrm{l} / \mathrm{m}^{2} / \mathrm{h}\right)$ was also experienced at the lower background concentration $(0.01 \mathrm{M})$ than at the higher background concentration (33.94 $1 / \mathrm{m}^{2} / \mathrm{h}$ ) This is also in agreement with findings of Dahmani and Chabene [8].

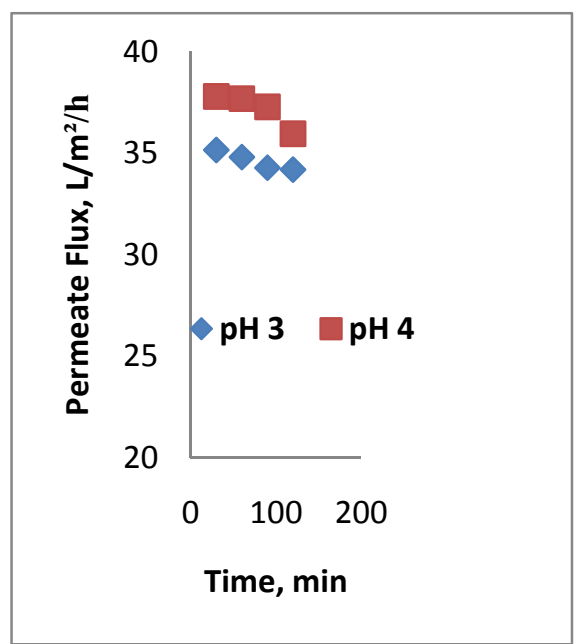

(a)

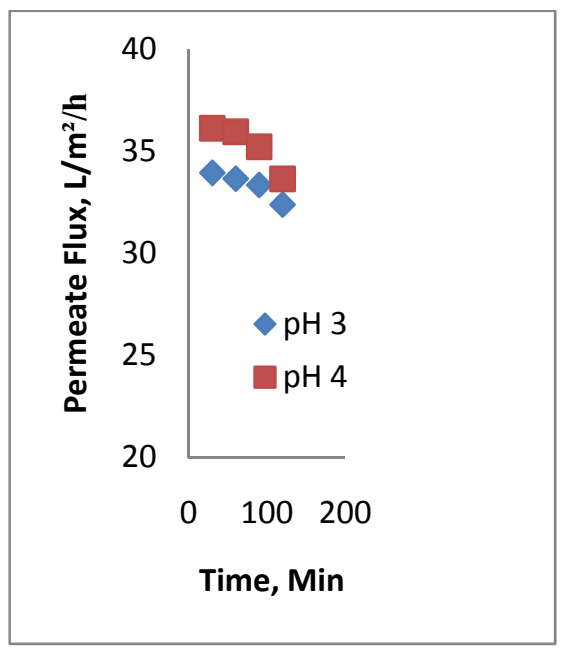

(b)

Figure 5: Effect of solution pH on Flux decline; (a) $0.01 \mathrm{M} \mathrm{NaCl}$ (b) $0.05 \mathrm{M}$ $\mathrm{NaCl}$ (30bar).

\subsection{Effects of solution $\mathrm{pH}$ and ionic strength on nickel ion rejection}

The effect of the solution $\mathrm{pH}$ on $\mathrm{Ni}$ ion rejection for the two $\mathrm{NaCl}$ background solutions $(0.01$ and $0.05 \mathrm{M})$ are shown in fig. 6. Higher $\mathrm{Ni}$ ion rejection (approximately 99.9\%) was experienced at the higher $\mathrm{pH}(\mathrm{pH} 4)$ for both background solutions. This could be ascribed to the higher flux at $\mathrm{pH} 4$. Lower ion rejections were obtained at a solution $\mathrm{pH}$ of 3 . Nickel ion rejection was about $95-96 \%$ at $0.01 \mathrm{M} \mathrm{NaCl}$ and $92-93 \%$ at $0.05 \mathrm{M} \mathrm{NaCl}$. Therefore, lower nickel ion rejections were obtained at the higher $\mathrm{NaCl}$ background $(0.05 \mathrm{M})$ solution. 


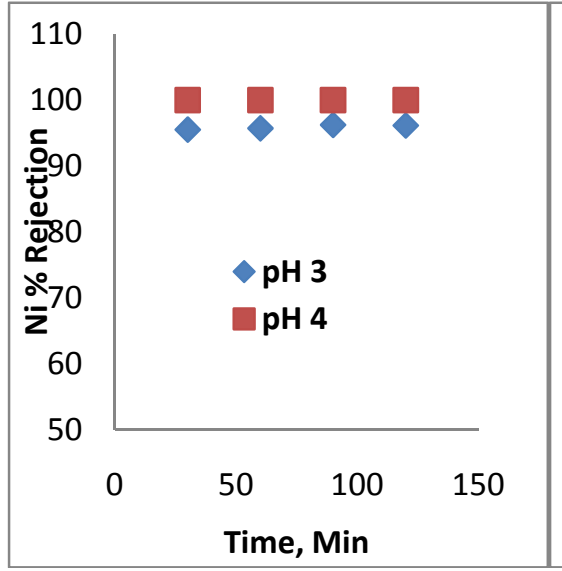

(a)

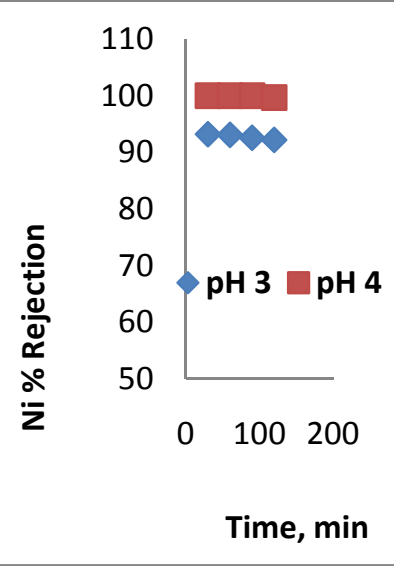

(b)

Figure 6: Effect of solution $\mathrm{pH}$ of on nickel ion rejection; (a) $0.01 \mathrm{M} \mathrm{NaCl}$ (b) $0.05 \mathrm{M} \mathrm{NaCl}$ (30 Bar).

\subsection{Clean water fluxes before and after exposure of the membrane to the nickel solutions}

The initial and final (after exposure of the membrane) clean water fluxes are shown in fig. 7. The initial clean water flux was a little bit higher than the clean water fluxes after exposure of the membrane to the solution. This indicated that the membrane surface was somewhat affected by the solution. Therefore, care should be taken to pretreat the water properly prior to treatment of real acid mine drainage to prevent fouling of the membrane.

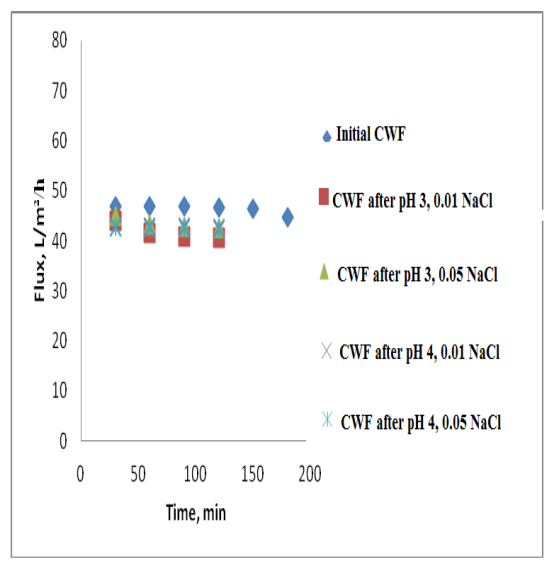

(a)

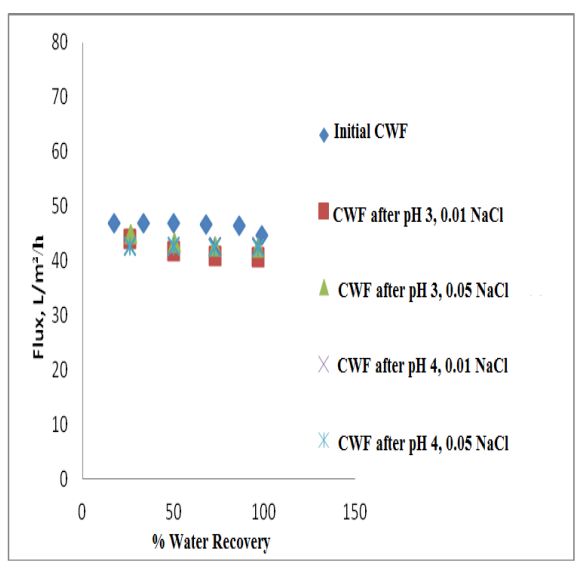

(b)

Figure 7: Flux of deionized water as function of (a) time; (b) water recovery (30 bar). 


\section{Conclusion}

The performance of a nanofiltration membrane for the removal of nickel ions from an aqueous solution was investigated using a dead-end test cell. The following conclusions can be made as a result of the investigation:

* Feed pressure has a significant effect on permeate flux. Permeate flux decreased from about $47 \mathrm{l} / \mathrm{m}^{2} / \mathrm{h}$ at 30 bar to about $16 \mathrm{l} / \mathrm{m}^{2} / \mathrm{h}$ at $10 \mathrm{bar}$.

* Permeate flux was higher $\left(47.61 \mathrm{l} / \mathrm{m}^{2} / \mathrm{h}\right)$ at the lower nickel concentration $(10 \mathrm{mg} / \mathrm{l})$ than at the higher nickel concentration $\left(100 \mathrm{mg} / \mathrm{l} ; 28.99 \mathrm{l} / \mathrm{m}^{2} / \mathrm{h}\right)$

* Nickel ion rejection was somewhat higher (96.97\%) at the higher nickel concentration $(100 \mathrm{mg} / \mathrm{l})$ than at the lower nickel concentration $(10 \mathrm{mg} / \mathrm{l}$; $86.78 \%$ ).

* Higher permeate flux $\left(37.791 / \mathrm{m}^{2} / \mathrm{h}\right)$ was experienced at the higher $\mathrm{pH}(\mathrm{pH}$ 4) than at the lower $\mathrm{pH}\left(\mathrm{pH} 3 ; 35.15 \mathrm{l} / \mathrm{m}^{2} / \mathrm{h}\right)$.

* Higher nickel ion rejection (99.9\%) was experienced at the higher $\mathrm{pH}(\mathrm{pH} 4)$ than at the lower $\mathrm{pH}(\mathrm{pH} 3 ; 95.5 \%)$.

* Higher permeate fluxes $\left(37.791 / \mathrm{m}^{2} / \mathrm{h}\right)$ were obtained at the lower ionic strength solution $(0.01 \mathrm{M})$ than at the higher ionic strength solution $(0.05 \mathrm{M}$; $\left.36.12 \mathrm{l} / \mathrm{m}^{2} / \mathrm{h}\right)$ at $\mathrm{pH} 4$.

* Higher nickel ion rejection (96.12\%) was obtained at the lower ionic strength $(0.01 \mathrm{M})$ than at the higher ionic strength $(0.05 \mathrm{M} ; 92.18 \%)$ at $\mathrm{pH} 3$

* The clean water flux after exposure of the membrane to the nickel solutions was somewhat lower than the initial clean water flux. Therefore, some membrane fouling took place.

* The membrane should be suitable for the removal of the nickel ion from acid mine drainage. However, flux is low and other membranes should also be evaluated.

\section{References}

[1] Nagajyoti, P. C., Lee K. D. and Sreekanth, T. V. M. Heavy metals, occurrence and toxicity for plants: a review. Environmental Chemistry Letter, 8(3), 199-216, 2010. Tanninen, J., Manttari, M. and Nystrom, M., Nanofiltration of concentrated acidic copper sulphate solutions. Desalination, 189 (1), pp. 92-96, 2006.

[2] Murthy, Z. V. P. and Chaudhari, L. B. Application of nanofiltration for the rejection of nickel ions from aqueous solutions and estimation of membrane transport parameters. Journal of Hazardous Materials, 160, pp. 70-77, 2008.

[3] Murthy, Z. V. P. and Chaudhari, L. B. Separation of binary heavy metals from aqueous solutions by nanofiltration and characterization of the membrane using spiegler-kedem model. Chemical Engineering Journal, 150, pp. 181-187, 2009.

[4] Csefalvay, E., Pauer V. and Mizsey, P. Recovery of copper from process waters by nanofiltration and reverse osmosis. Desalination 240, pp. 132$142,2009$. 
[5] Akbari, A., Homayoonfal, M. and Jabbari, V. Effect of solution chemistry and operating conditions on the nanofiltration of acid dyes by a nanocomposite membrane. Water Science and Technology, 64(12), pp. 2404-2409, 2011.

[6] Dipankar, N., Kuo-Lun, T., Chi-Chung, H., Ching-Jung, C., Ruoh-Chyu, R., Yan-Che C., Chih-Shen, C. and Tien-Hwa, W. Effect of solution chemistry on water softening using charged nanofiltration membranes. Desalination, 234, pp. 344-353, 2008.

[7] Schäfer, A.I., Pihlajamäki, A., Fane, A.G., Waite, T.D. and Nyström, M. Natural organic matter removal by nanofiltration: effects of solution chemistry on retention of low molar mass acids versus bulk organic matter. Journal of Membrane Science, 242(1-2), pp. 73-85, 2004.

[8] Dahmani, B. and Chabene, M. Effect of solution chemistry on nanofiltration membranes of nickel removal from aqueous solution. Chemical Engineering and Process Technology, 2(1), pp. 103-107, 2011.

[9] Choo, K. H., Kwon, D. J., Lee, K. W. and Choi, S. J. Selective removal of cobalt species using nanofiltration membranes. Environmental Science Technology, 36(6), pp. 1330-1336, 2002. 